\title{
PELATIHAN DESAIN GRAFIS MENGGUNAKAN APLIKASI CANVA UNTUK PELAKU USAHA TOKO IKAN "SUB AQUATIC" SEBAGAI STRATEGI DIGITAL MARKETING
}

\author{
Nuril Esti Khomariah, Puteri Noraisya Primandari \\ Universitas 17 Agustus 1945 Surabaya \\ nuril@untag-sby.ac.id, puterinoraisya@untag-sby.ac.id
}

\begin{abstract}
Technological developments, especially in the field of graphic design, have had a significant impact on the world of marketing. Graphic design can be a more interesting and unique communication medium because it has images and text with very beautiful colors to look at. More and more business people are using graphic design to be their marketing media, such as posters, banners, logos, etc. However, there are still many fish shop business actors who still use conventional marketing techniques, namely by opening shops in the fish market and its surroundings. Sub Aquatic is one of the sellers and fish breeders in Surabaya who will be partners in this service activity. The main goal is to utilize graphic design as a marketing strategy through digital marketing. The application that will be used is Canva. The choice of this application is because it is very easy to use and there are lots of interesting image content that can be used. Business owners will be taught how to create attractive graphic design content to upload on their social media accounts. As well as techniques in the selection of color combinations and the size of text and images. The result is that business owners have the knowledge to create interesting content using the Canva application. Partners have a logo as the hallmark of their business. This business social media account attracts more visitors and increases sales turnover.
\end{abstract}

Keywords: Fish; Design; Digital; Canva

\begin{abstract}
Abstrak
Perkembangan teknologi khususnya di bidang desain grafis sangat membawa dampak yang signifikan di dunia pemasaran. Desain grafis dapat menjadi media komunikasi yang lebih menarik dan unik karena memiliki gambar dan teks dengan warna-warna yang sangat indah untuk dilihat. Semakin banyak pelaku usaha yang memanfaatkan desain grafis untuk menjadi media pemasaran mereka, seperti poster, banner, logo dll. Namun masih banyak para pelaku usaha toko ikan yang masih menggunakan teknik pemasaran konvensional, yaitu dengan membuka toko di pasar ikan dan sekitarnya. Sub Aquatic adalah salah penjual dan peternak ikan di Surabaya yang akan menjadi partner dalam kegiatan pengabdian ini. Tujuan utamanya adalah untuk memanfaatkan desain grafis sebagai salah satu strategi pemasaran melalui digital marketing. Aplikasi yang akan dipakai yaitu Canva. Pemilihan aplikasi ini adalah karena sangat mudah digunakan dan sangat banyak sekali konten-konten gambar menarik yang dapat dipakai. Pemilik usaha akan diajari bagaimana cara membuat suatu konten desain grafis yang menarik untuk di upload di akun media social mereka. Serta Teknik-teknik dalam pemilihan kombinasi warna-warna serta ukuran teks dan gambar. Hasil yang dicapai adalah pemilik usaha memiliki pengetahuan dalam membuat konten-konten menarik menggunakan aplikasi Canva. Mitra memiliki logo sebagai ciri khas dari usaha mereka. Akun media social usah ini lebih menarik pengunjung serta omzet penjualan naik. Kata Kunci: Ikan; Desain; Digital, Canva,
\end{abstract}

Submitted: 2021-05-17 Revised: 2021-07-15 Accepted: 2021-07-31 


\section{Pendahuluan}

Ikan merupakan hewan yang paling sering dipilih ketika seseorang sedang memulai belajar untuk memiliki hewan peliharaan. Karena beberapa ikan hanya membutuhkan sedikit perawatan sehingga tidak terlalu membebani sang pemilik. Selain itu juga dengan melihat ikan berwarna-warni dipercayai dapat membuat lebih rileks sehingga dapat mengurai stress dan kepenatan. Semakin perkembanganya teknologi terutama di bidang desain grafis memiliki dampak yang baik bagi perkembangan pelaku usaha. Mereka lebih mudah dalam memasarkan produk salah satunya melalui marketplace. Tentu saj hal ini harus diimbangi dengan media komunikasi yang menarik salah satunya adalah desain grafis.

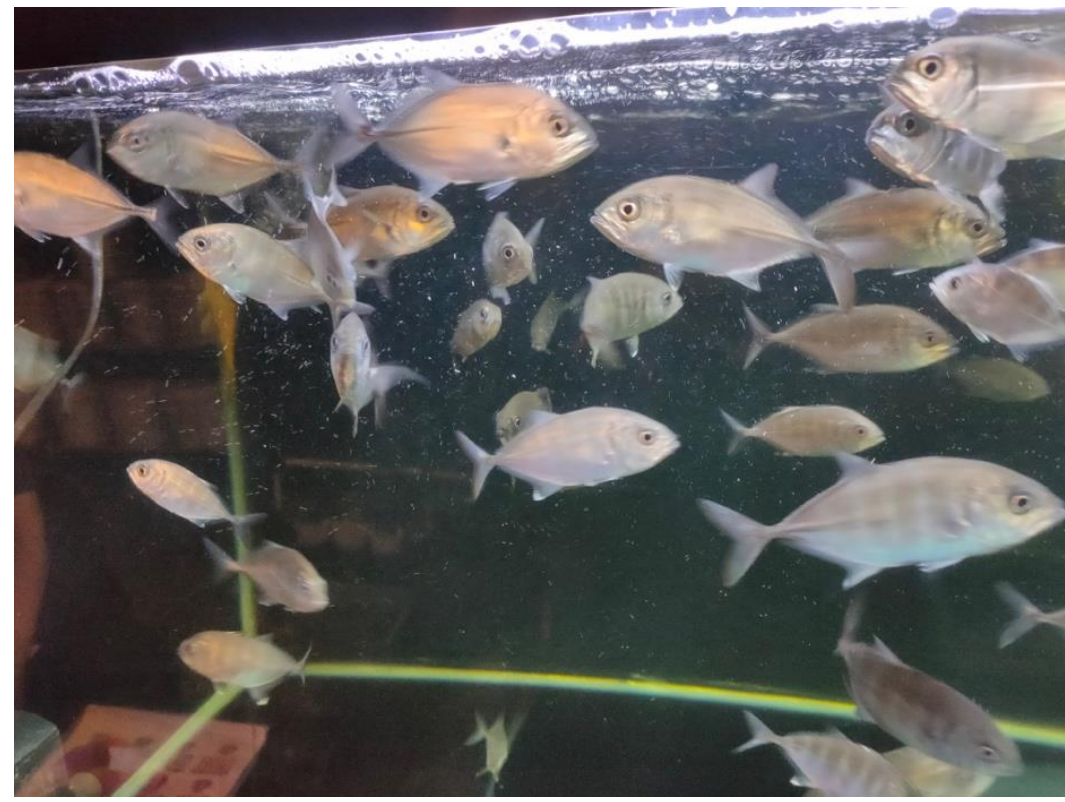

Gambar 1. Produk mitra ikan predator

Namun kebanyakan dari para pelaku usaha tidak memiliki pengetahuan yang baik mengenai digital marketing dan desain grafis. Maka dari itu pemilihan software / aplikasi yang digunakan akan sangat berpengaruh. Telah banyak sekali pelatihan desain grafis akan menggunakan aplikasi Canva (Zaman,2020)(Sakinah,2020)(Pelangi,2020). Aplikasi ini sangat mudah digunakan oleh orang awam sekalipun. Pemanfaatan media social bagi pelaku usaha toko ikan juga semakin ramai dilakukan (Khomariah,2021). Hal ini tentu saja sangat memiliki dampak tinggi pada penjualan (Yapanto,2020).

Tidak hanya pada toko ikan saja, namun para pelaku peternakan ikan juga mulai memanfaatkan digital marketing pada strategi pemasarannya mereka (Latianingsih,2021). Selain itu para pengusaha hasil olahan ikan berupa kerupuk juga mulai ramai menerapkan marketing online (Novarini,2020). Sehingga dapat ditarik kesimpulan bahwa digital marketing adalah sesuatu yang wajib untuk dilakukan bagi para pelaku usaha di masa kini. Kunci utama dalam digital marketing adalah akun media social dan konten yang menarik. Terlebih lagi di masa pandemi dimana aktifitas diluar banyak dikurangi, tentu saja berakibat konsumen offline akan sangat berkurang. Maka pilihan satu-satunya bagi pelaku usaha adalah memasarkan produknya secara online (Zuhri, 2021). 
BERNAS:

\section{Metode}

Metode pelaksanaan kegiatan pengabdian masyarakat ini dibagi menjadi beberapa tahapan yaitu :

\section{Tahap Persiapan}

Tahapan ini diawalai dengan melakukan observasi ke lokasi mitra. Lalu mengamati kondisi dan melakukan wawancara sehingga lebih dalam mengetahui kondisi usaha mitra. Sehingga masalah dapat di identifikasi dengan baik. Selanjutnya adalah menyiapkan bahan materi yang sesuai untuk menyelesaikan permasalahan mitra.

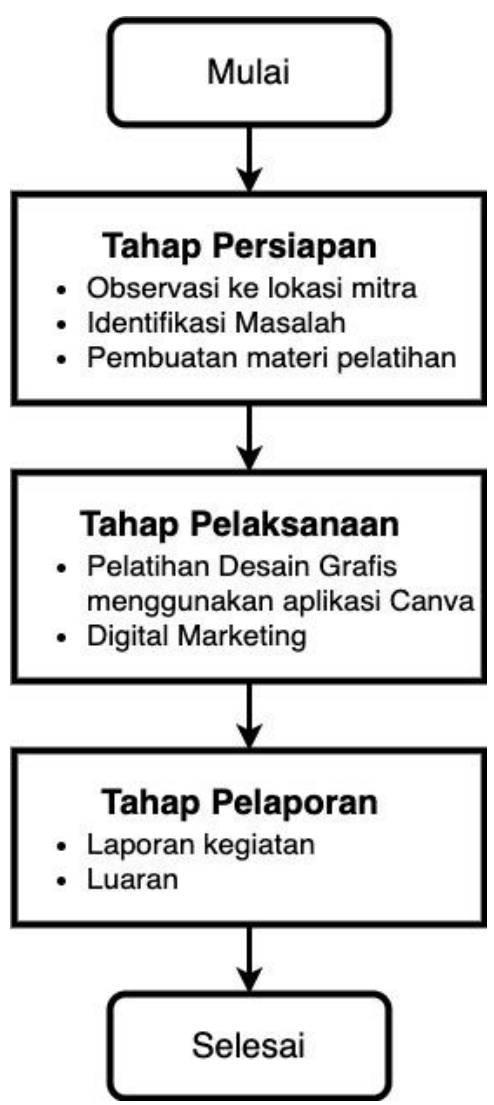

Gambar 2 Metode Pelakasanaan Kegiatan

\section{Tahap Pelaksanaan}

Setelah menyelesaikan tahap persiapan, maka dilanjutkan ke tahap pelaksanaan. Pada tahap ini tim pengabdi memberikan soluasi atas permasalahan mitra. Solusi ini harus tetap sasaran sesuai dengan permasalahan yang dihadapi mitra.

Adapun kegiatan sosialisasi atau pelatihan yang dilaksanakan sebagai berikut :

a) Sosialisasi pentingnya pemanfaatan social media untuk pemasaran

b) Pelatihan pembuatan desain logo menggunakan aplikasi Canva

c) Pelatihan pembuatan desain konten Instagram

d) Digital marketing yang sesuai dengan jenis usaha mitra

3. Tahap Pelaporan 
Tahap yang paling terakhir adalah tahap pelaporan. Pada tahap ini tim pengabdi membuat laporan hasil kegiatan dan juga membuat luaran-luaran dari kegiatan pengabdian ini.

\section{Hasil dan Pembahasan}

Hasil dari kegiatan pengabdian ini adalah sebuah desain grafis logo dari usaha toko ikan dan beberapa konten untuk di upload ke media social Instagram. Langkah pertama untuk membuat sebuah logo adalah membuka aplikasi Canva secara online di alamat canva.com. Maka akan tampil beberapa pilihan yang sudah disediakan yaitu presentasi, kartu nama bisnis, logo, poster, kiriman Instagram, daftar riwayat hidup, kartu, selebaran, brosur, dokumen A4, dll.

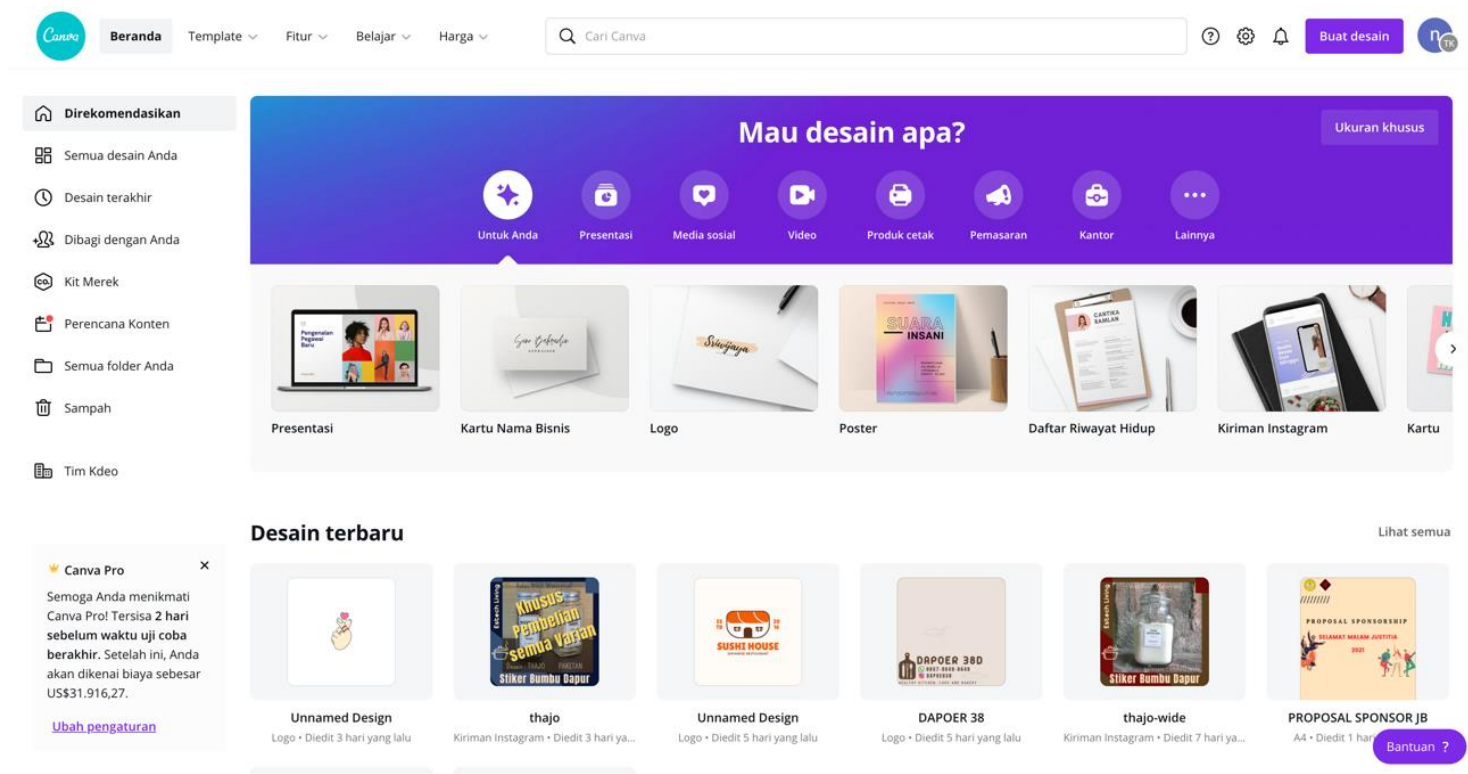

Gambar 3. Tampilan awal aplikasi Canva

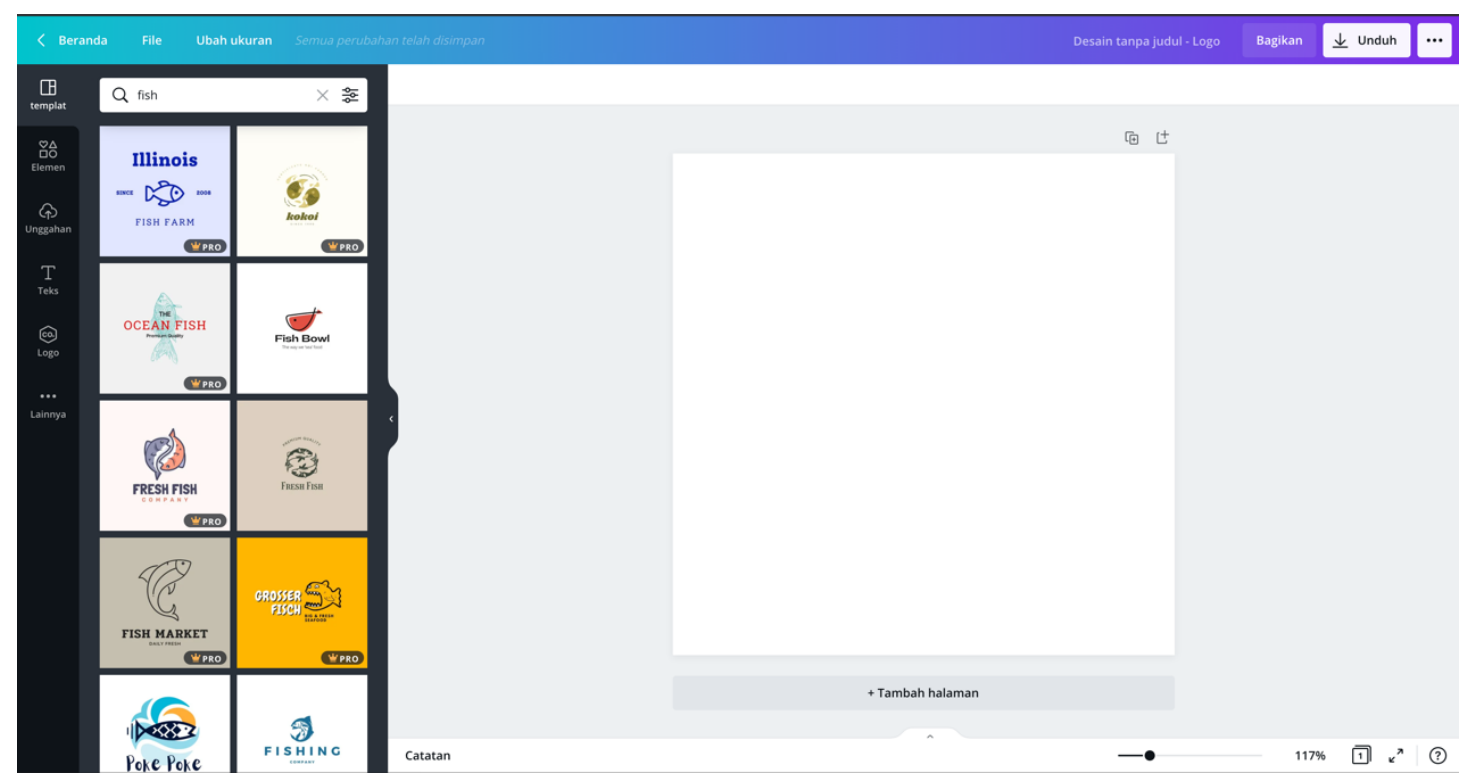

Gambar 4. Tampilan Ketika memilih pembuatan logo 
Disebelah kiri sudah disediakan template logo-logo yang dapat digunakan. Masukkan kata kunci ikan lalu akan muncul konten-konten gambar yang sesuai dengan kata kunci ynag dimasukkan. Selanjutnya kita dapat melakukan penambahan teks dan gambar.

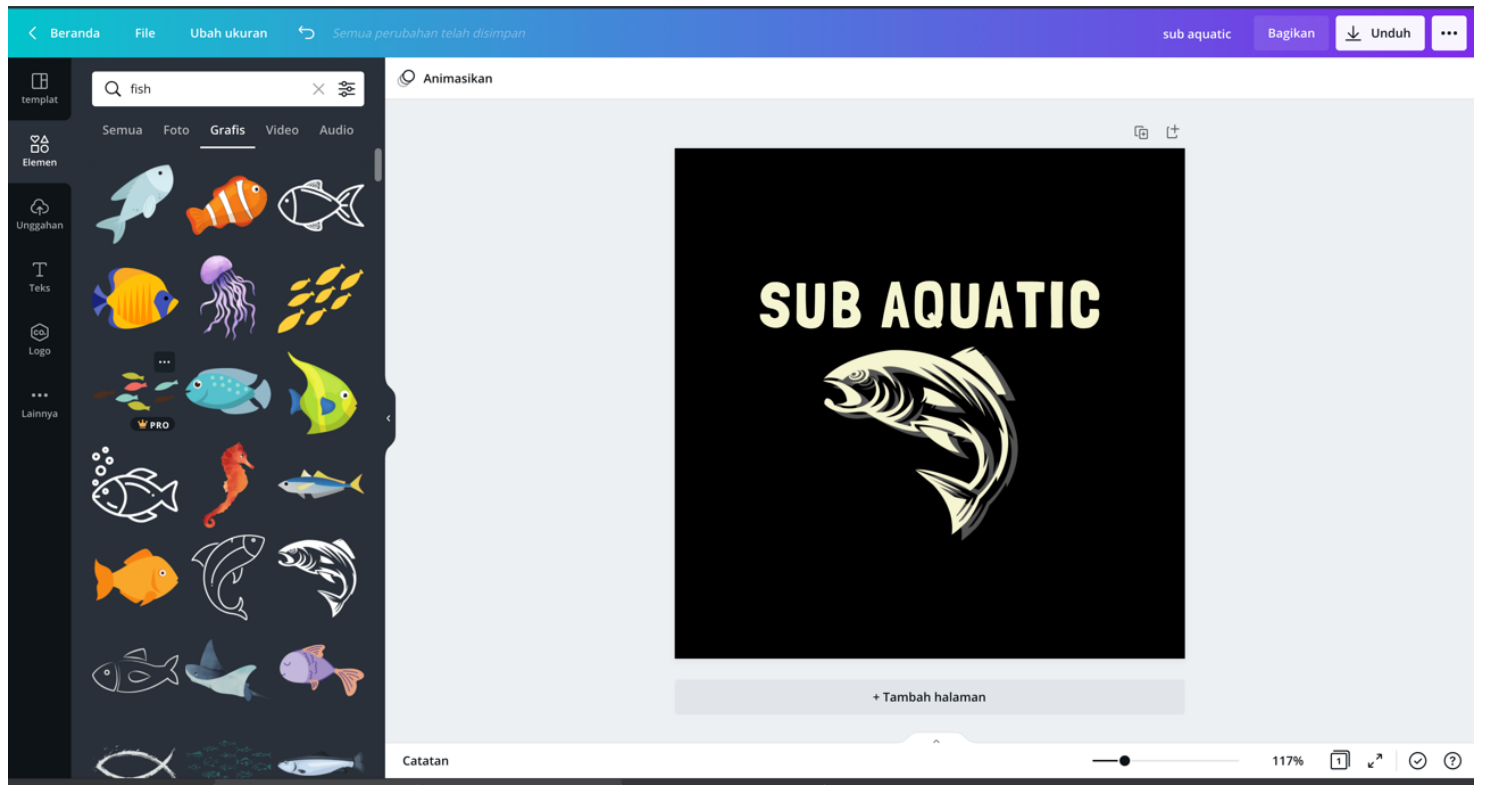

Gambar 5. Proses pembuatan logo

Langkah selanjutnya adalah mengunduh desain tersebuh, dengan beberapa pilihan file format gambar.
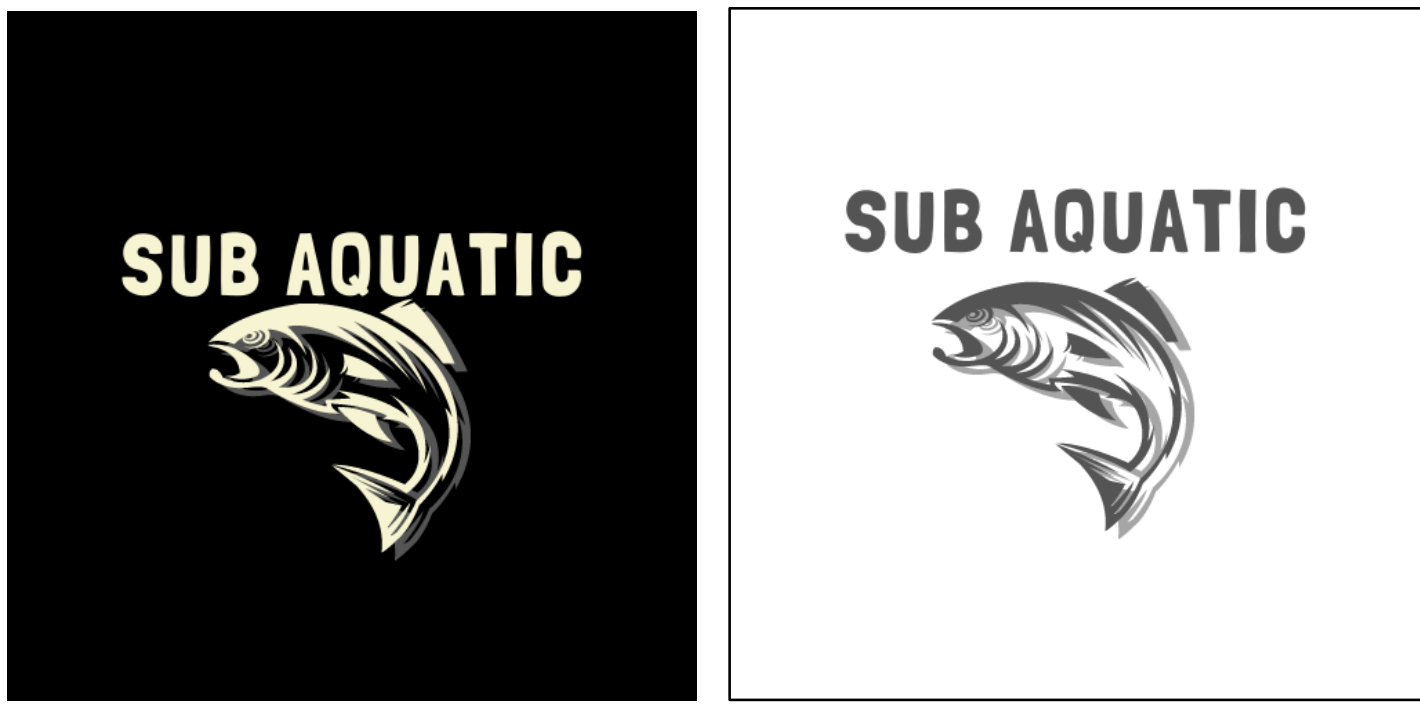

Gambar 6. Hasil jadi logo

Hasil dari kegiatan pengabdiam masyarakat ini adalah sebuah desain grafis logo yang menjadi identitas usaha mitra. Logo didesain sesuai dengan jenis usaha yaitu toko ikan. Aplikasi Canva dipilih karena sangat mudah sekali digunakan. Tim pelaksana memandu step by step bagaimana cara untuk membuat logo yang baik dan menarik. Hasil dari desain logo Sub Aquatic dapat dilihat pada Gambar 6. Pada logo tertera nama dari usaha mitra yaitu SUB AQUATIC dan dibagian bawah diberi gambar vector ikan. 

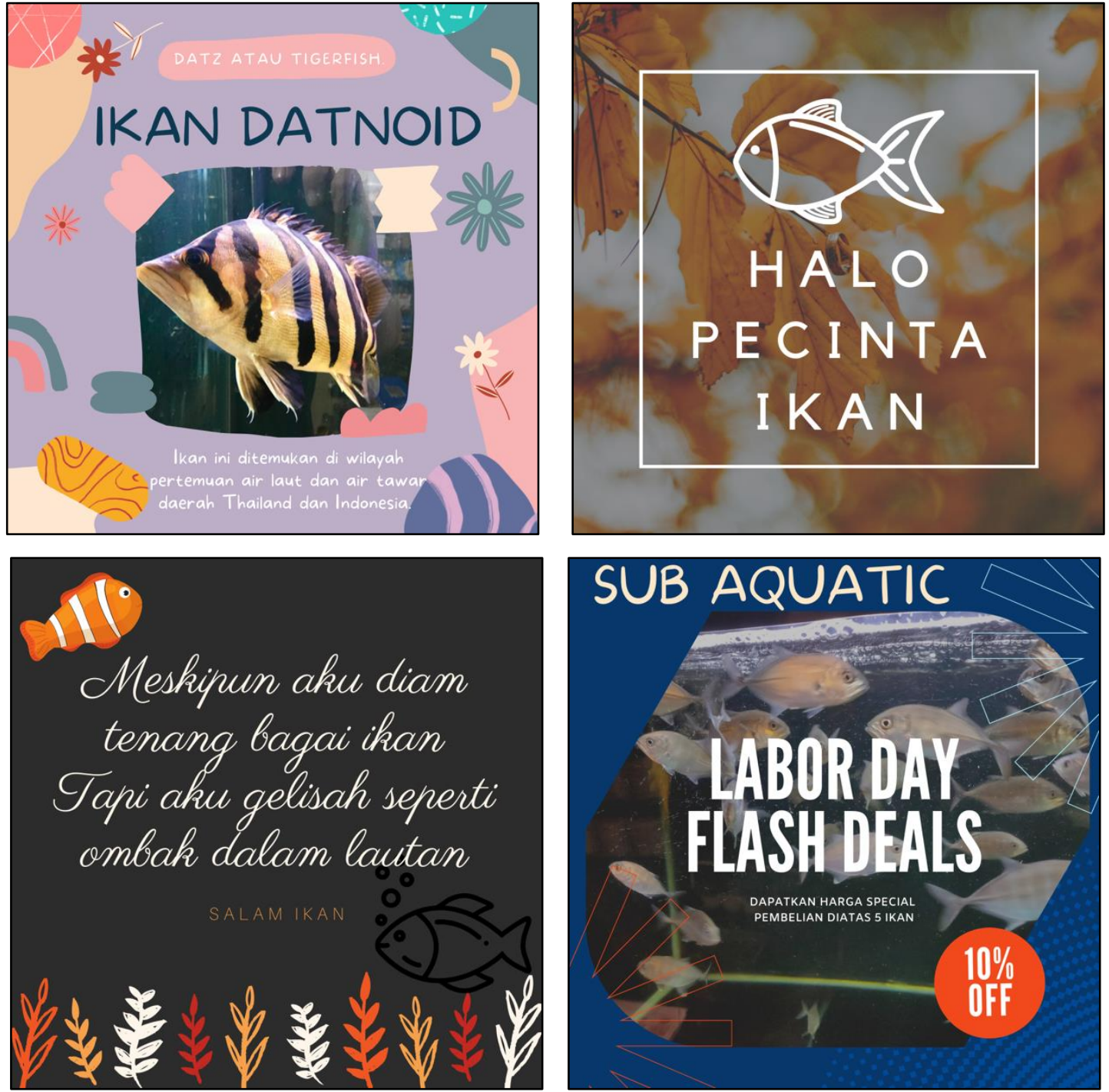

Gambar 7. Hasil konten untuk di upload di Instagram

Pada gambar 7 terlihat beberapa hasil konten yang dapat digunakan untuk mengisi akun media social / Instagram. Pemilihan kombinasi warna-warna cerah kan lebih menarik bagi konsumen. Serta pemberian diskon / promo disaat event hari libur tertentu juga akan sangat efektif.

\section{Kesimpulan}

Tujuan utama dari pelaksanaan kegiatan pengabdian masyarakat ini adalah mengenalkan mitra pada manfaat social media dan digital marketing. Dimana target utamanya adalah untuk menaikkan omzet penjualan. Selain itu juga membuat branding produk yang akhirnya akan menaikkan daya saing usaha. Hasil dari sosialisasi yang telah dilakukan adalah mitra mengetahui cara memanfaatkan social media. Sedangkan dari pelatihan, mitra sudah dapat membuat logo dan konten media sosial sendiri.

\section{Daftar Pustaka}

Zaman, A. N. (2020). Pemberdayaan dan Pelatihan Desain Grafis Bisnis Kekinian pada Desa Limo. Widya Laksana, 9(1), 6-10. 
Sakinah, L., Rahmawati, N., \& Salman, H. (2020). Pelatihan Desain Grafis Menggunakan Aplikasi Canva Tingkat Smk Di Smkn 1 Gunung Putri Bogor. BERNAS: Jurnal Pengabdian Kepada Masyarakat, 1(4), 476-480.

Pelangi, G. (2020). Pemanfaatan Aplikasi Canva Sebagai Media Pembelajaran Bahasa dan Sastra Indonesia Jenjang SMA/MA. Jurnal Sasindo UNPAM, 8(2), 79-96.

Khomariah, N. E. (2021). Implementasi Pemasaran Ikan Hias "Sub Betta Brothers" Melalui Social Media Dan Digital Marketing. BERNAS: Jurnal Pengabdian Kepada Masyarakat, 2(1), 196-201.

Yapanto, L. M. (2020). Tataniaga Dan Margin Pemasaran Ikan Tuna Di Kota Gorontalo. Jambura Journal of Animal Science, 2(2), 38-45.

Latianingsih, N., Suyanti, D. W., Martina, N., \& Mariam, I. (2021). Strategi Marketing 4.0 pada Pasca Panen Ikan Lele di Desa Curug Kecamatan Gunung Sindur Kabupaten Bogor. Jurnal Komunitas: Jurnal Pengabdian kepada Masyarakat, 3(2), 72-76.

Latianingsih, N., Susyanti, D. W., Martina, N., \& Mariam, I. (2021, February). Strategi Marketing 4.0 Ikan Lele Pasca Panen. In PROSIDING SEMINAR NASIONAL LPPM UMP (pp. 631-637).

Novarini, N., Sukadi, S., \& Porawati, H. (2020). Metode Penjualan Kerupuk Ikan Secara Online Di Desa Bagan Pete Kecamatan Alambarajo Kota Jambi Untuk Menghadapi Masa Pandemik Covid-19. SNAPTEKMAS, 2(1).

Zuhri, A. R., Nawawi, M. K., \& Gustiawati, S. (2021). Pengaruh Pemasaran Online terhadap Usaha Ikan Hias Dalam Perspektif Ekonomi Syariah pada Masa Pandemi Covid-19. El-Mal: Jurnal Ekonomi \& Bisnis Islam, 4(2), 184-193. 